\title{
MENINGKATKAN KEMANDIRIAN BELAJAR SISWA SMP DALAM MATEMATIKA DENGAN MENGGUNAKAN PENDEKATAN SAINTIFIK
}

\author{
Gida Kadarisma \\ STKIP Siliwangi Bandung \\ gidakadarisma@yahoo.com
}

\begin{abstract}
Abstrak: Penelitian ini bertujuan untuk menganalisis peningkatan kemandirian belajar siswa SMP di salah satu SMP di Kota Cimahi antara yang menggunakan pendekatan saintifik dengan yang menggunakan pendekatan konvensional, mengingat pendekatan saintifik adalah pendekatan pembelajaran yang wajib diterapkan dalam kurikulum 2013. Sampel dalam penelitian ini adalah salah satu SMP di Kota Cimahi yang sudah menggunakan kurikulum 2013 sebagai acuan kurikulumnya yang dipilih sebanyak 2 kelas yaitu kelas pertama menggunakan pendekatan saintifik dan kelas kedua menggunakan pendekatan konvensional. Instrumen dalam penelitian ini adalah soal non tes berupa angket yang terdiri dari 30 pernyataan, 16 pernyataan positif dan 14 pernyataan negatif. Hasil dari Penelitian ini adalah Peningkatan kemandirian belajar siswa SMP yang menggunakan pendekatan saintifik lebih baik daripada yang menggunakan pendekatan konvensional.
\end{abstract}

Kata Kunci : Kemandirian Belajar, Pendekatan Saintifik

\section{A. PENDAHULUAN}

Pada era globalisasi saat ini, kemampuan kita dalam mengatur diri sendiri dan menentukan target adalah hal yang sangat penting, begitupun dalam pembelajaran matematika sebagai siswa tentunya mengontrol diri sendiri dalam belajar serta menentukan target belajar sangat diutamakan demi tercapainya tujuan belajar siswa itu sendiri kemampuan tersebut biasa disebut dengan kemandirian belajar.

Kemandirian Belajar merupakan sebuah proses yaitu siswa mengatur tercapainya hasil dan aksi mereka sendiri. Menentukan target untuk mereka, mengevaluasi kesuksesan mereka saat mencapai target tersebut dan memberikan penghargaan pada diri mereka sendiri karena telah mencapai tujuan tersebut. Kemandirian belajar dari kognisi dan tingkahlaku adalah aspek yang sangat penting dalam belajar siswa dan hasil akademik dalam kelas.

Hal ini senada dengan apa yang diungkapkan oleh Bandura (Friedman, 2006) ia menyatakan bahwa kemandirian belajar yaitu proses dimana seseorang dapat mengatur pencapaian dan aksi mereka sendiri dengan menentukan target, mengevaluasi kesuksesan seseorang saat mencapai target dan memberikan penghargaan karena telah mencapai tujuan tertentu. Selain itu kemandirian belajar diartikan juga sebagai pengawasan atau perilaku dalam proses belajar sebagai hasil dari proses internal akan tujuan, perencanaan, dan penghargaan akan diri sendiri atas prestasi yang telah diraih. 
Menurut Fauzi (2011) Pentingya kemandirian dalam belajar matematika karena tuntutan kurikulum agar siswa dapat menghadapi persoalan di dalam kelas maupun di luas kelas yang semakin kompleks dan mengurangi ketergantungan siswa dengan orang lain dalam kehidupan sehari-hari

Kemandirian diri siswa dalam belajar dapat tumbuh melalui pendekatan pembelajaran yang guru sajikan dalam kelas, pendekatan pembelajaran yang diteliti adalah pendekatan saintifik. Pendekatan ini menjadi sesuatu yang muncul saat kurikulum 2013 diberlakukan. Guru wajib menggunakan pendekatan saintifik dalam pembelajaran oleh karena itu peneliti tertarik unttuk meneliti pengaruh kemandirian belajar siswa dengan menggunakan pendekatan saintifik.

Pendekatan saintifik pertama kali diperkenalkan ke ilmu pendidikan Amerika pada akhir abad ke-19, sebagai penekanan pada metode laboratorium formalistik yang mengarah pada fakta-fakta ilmiah.Menurut Varelas dan Ford (2009) pendekatan saintifik ini memiliki karakteristik "doing science". Metode ini memudahkan guru atau pengembang kurikulum untuk memperbaiki proses pembelajaran, yaitu dengan memecah proses ke dalam langkah-langkah atau tahapan-tahapan secara terperinci yang memuat instruksi untuk siswa melaksanakan kegiatan pembelajaran, Hal inilah yang menjadi dasar dari pengembangan kurikulum 2013 di Indonesia.

Dalam Standar Kompetensi Lulusan (SKL), sasaran untuk pembelajaran mencakup pengembangan ranah sikap, pengetahuan, dan keterampilan yang dielaborasi untuk setiap satuan pendidikan. Ketiga ranah kompetensi tersebut memiliki lintasan perolehan (proses psikologi) yang berbeda. Sikap diperoleh melalui aktivitas "menerima, menjalankan, menghargai, menghayati, dan mengamalkan". Pengetahuan diperoleh melalui aktivitas " mengingat, memahami, menerapkan, menganalisis, mengevaluasi, dan mencipta". Keterampilan diperoleh melalui aktivitas "mengamati, menanya, mencoba, menalar, menyaji, dan mencipta".

Karakteristik kompetensi beserta perbedaan lintasan perolehan turut serta mempengaruhi karakteristik standar proses (Permen No.65 Tahun 2013). Pendekatan scientific dalam pembelajaran sebagaimana dimaksud meliputi mengamati, menanya, menalar, mencoba, membentuk jejaring untuk semua mata pelajaran. Untuk memperkuat pendekatan saintifik diperlukan adanya penalaran dan sikap kritis siswa dalam rangka pencarian (penemuan). Agar dapat disebut ilmiah, metode pencarian (method of inquiry) harus berbasis pada bukti-bukti dari objek yang dapat diobservasi, empiris, dan terukur dengan prinsip-prinsip penalaran yang spesifik. Karena itu metode ilmiah umumnya memuat rangkaian kegiatan koleksi data atau fakta melalui observasi dan eksperimen, kemuadian memformulasi dan menguji hipotesis.Menurut Kemendikbud (2013) Sebenarnya apa yang dibicarakan dengan metode ilmiah merujuk pada: (1) adanya fakta, (2) sifat bebas prasangka, (3) sifat objektif, dan (4) adanya analisa. Dengan metode ilmiah seperti ini diharapkan kita akan mempunyai sifat kecintaan pada kebenaran yang objektif, tidak gampang percaya pada hal-hal yang tidak rasional, ingin tahu, tidak mudah membuat prasangka, selalu optimis. 
Sesuai pemaparan diatas karena dalam pendekatan saintifik terdapat beberapa karakteristik seperti inquiri, menanya dan menalardiharapkan kemandirian belajar siswa menjadi meningkat.

Oleh karena itu tujuan dari penelitian ini adalah untuk mengetahui apakah peningkatan kemandirian belajar siswa yang belajarnya menggunakan pendekatan saintifik lebih baik daripada yang menggunakan pendekatan konvensional

\section{B. METODE PENELITIAN}

Metode dalam penelitian ini adalah kuasi eksperimen dengan desain kelompok kontrol pretes-postes, karena ada pemanpulasian perlakuan kelas yang pertama menggunakan pendekatan saintitifk dan kelas kedua menggunakan pendekatan konvensional. Sampel dalam penelitian ini adalah dua kelas di salah satu SMP di Kota Cimahi . Disain penelitiannya (Ruseffendi, 2010) :

O X O

$\mathrm{O}$

$\mathrm{O}$

Keterangan

$\mathrm{O} \quad$ : Angket kemandirian belajar

$\mathrm{X} \quad$ : Pembelajaran menggunakan pendekatan saintifik

- - - - : Pengambilan sampel tidak secara acak

Angket mengenai kemandirian siswa diberikan sebelum dan setelah eksperimen dimulai. Angket kemandirian belajar ini terdiri dari 30 pertanyaan (16 pernyataan positif dan 14 pernyataan negatif) yang terdiri dari 9 indikator. Skala yang digunakan adalah skala likert, menurut Sugiyono (2010) skala likert digunakan untuk mengukur sikap, pendapat, dan persepsi seseorang atau sekelompok orang tentang fenomena sosial.

\section{HASIL PENELITIAN}

Angket diberikan sebelum dan sesudah eksperimen dilakukan kepada kedua kelas yaitu kelas kontrol dan kelas eksperimen, dibawah ini merupakan statistika deskriptif dari kedua kelas sebelum dan setelah eksperimen :

\section{Tabel 1}

Statistika Deskriptif Angket Kemandirian Belajar

\begin{tabular}{|c|c|c|c|c|c|c|}
\hline \multirow{2}{*}{ Kelas } & \multicolumn{2}{|c|}{$\begin{array}{c}\text { Sebelum } \\
\text { Eksperimen }\end{array}$} & \multicolumn{3}{c|}{$\begin{array}{c}\text { Setelah } \\
\text { Eksperimen }\end{array}$} \\
\cline { 2 - 7 } & $\mathbf{X}$ & $\mathbf{S}$ & $\mathbf{N}$ & $\mathbf{X}$ & $\mathbf{S}$ & $\mathbf{N}$ \\
\hline Konvensional & $\mathbf{7 9 . 0 2}$ & $\mathbf{6 . 9 5}$ & $\mathbf{3 0}$ & $\mathbf{8 2 . 5 4}$ & $\mathbf{7 . 2 7}$ & $\mathbf{3 0}$ \\
\hline Saintifik & $\mathbf{8 0 . 2 0}$ & $\mathbf{9 . 6 0}$ & $\mathbf{2 8}$ & $\mathbf{9 2 . 3 2}$ & $\mathbf{5 . 9 8}$ & $\mathbf{2 8}$ \\
\hline
\end{tabular}


Dari Tabel 1 diatas dapat terlihat rata-rata skor angket kelas saintifik sebelum eksperimen adalah 80.20 dengan simpangan baku 9.60, sedangkan yang menggunakan konvensional tidak jauh berbeda yaitu 79,02 dengan simpangan baku 6,95. Namun Setelah eksperimen, skor angket kemandirian belajar menjadi meningkat, kelas yang menggunakan konvensional 82,54 dan yang menggunakan saintifik 92,32.

Karena data dari kemandirian belajar berbentuk peringkat maka untuk mengetahui perbedaan peningkatan keduanya menggunakan uji nonparametrik Mann-Whitney. Berikut hasil pengolahan datanya:

Tabel 2

\section{Uji Mann-Whitney Peningkatan Kemandirian Belajar Siswa} Setelah Eksperimen

\begin{tabular}{|c|c|}
\hline \multicolumn{2}{|c|}{ Test Statistics ${ }^{a}$} \\
\hline & GAIN_KB \\
\hline $\begin{array}{l}\text { Mann-Whitney U } \\
\text { Wilcoxon W } \\
\text { Z } \\
\text { Asymp. Sig. (2- } \\
\text { tailed) }\end{array}$ & $\begin{array}{r}125.500 \\
780.500 \\
-3.543 \\
.000\end{array}$ \\
\hline
\end{tabular}

a. Grouping Variable:

PENDEKATAN

Berdasarkan Tabel 2 di atas dapat dilihat bahwa signifikansi Asymp. Sig. (2-tailed) sebesar 0,00, sehingga sig untuk 1-tailed 0,00 /2=0,00 yang artinya lebih kecil dari $\alpha=0,05$. Sehingga $\mathrm{H}_{0}$ diterima, artinya peningkatan kemandirian belajar siswa yang menggunakan pendekatan saintifik lebih baik daripada yang menggunakan pendekatan konvensional.

\section{PEMBAHASAN DAN KESIMPULAN}

Peneliti akan menguraikan beberapa penemuan yang ada dilapangan saat eksperimen berlangsung, tidak mudah memang dalam meneliti mengenai kemandirian belajar siswa karena butuh waktu yang cukup lama dalam meneliti sikap seseorang, sedangkan penelitian hanya berlangsung 6 kali pertemuan saja. Peneliti memerhatikan phase-phase dalam kemandirian belajar siswa,menurut Schunk dan Zimmerman (Sumarmo, 2004) terdapat tiga phase utama dalam siklus kemandirian belajar yaitu: merancang belajar, memantau kemajuan belajar selama menerapkan rancangan, dan mengevaluasi hasil belajar secara lengkap.

Ada beberapa faktor yang dapat menyebabkan seseorang kurang mampu untuk mengembangkan kemandirian belajar menurut Brody, Stoneman \& Flor dalam ( Boekaerts, 2000). pengalaman belajar yang kurang di lingkungan sosial adalah faktor yang pertama yang menyebabkan hambatan seseorang dalam mengembangkan kemandirian belajar. Seringkali mereka 
mengalami kesulitan untuk mengembangkan kemandirian belajar disebabkan mereka tumbuh di rumah atau lingkungan yang tidak mengajarkan mereka untuk melakukan kemandirian belajar, tidak diberikan contoh, atau pun tidak diberikan penghargaan, Hambatan berikutnya menurut Steinberg dkk dalam (Boekaerts, 2000) adanya sikap apatis , Hal ini disebabkan dalam menggunakan teknik-teknik kemandirian belajaryang efektif dibutuhkan atisipasi, konsentrasi, usaha, self reflection yang cermat. Misalnya dalam pembelajaran anak yang pendiam dan kurang pandai cenderung tidak antusias dalam pembelajaran berlangsung dan jarang mengumpulkan tugas, hambatan berikutnya menurut Bandura dalam (Boekaerts, 2000) adalah Gangguan suasana hati, seperti mania atau depresi adalah batasan ketiga yang dapat menyebabkan disfungsi kemandirian belajar. Misalnya seseorang yang memiliki masalah dalam keluarga atau siswa yang broken home kebanyakan akan membawa masalahnya dalam pembelajaan mereka cenderung pendiam dan tidak konsentrasi dalam belajar sehingga pengembangan kemandirian belajar terhambat.

Hambatan-hambatan tersebut ditemukan juga pada saat penelitian berlangsung, mengingat usia SMP siswa cenderung belum stabil, dan masih banyak bermain-main pada saat berlangsung, namun saat langkah-langkah dalam pendekatan saintifik disajikan siswa lebih tertarik karena tahapannya membuat mereka bisa belajar mandiri, saat tahap mengkomunikasikan siswa lebih aktif menyampaikan pendapat mereka sesuai hasil kesepakatan dengan rekan sekelompoknya. Penilaian autentik sangat mendukung guru dalam menilai afektif siswa selama pembelajaran berlangsun, hal ini sesuai dengan hasil kajian dari Susilana dan ihsan (2014) yang menyatakan Kegiatankegiatan yang dikembangkan dalam pendekatan saintifik dapat memicu muncul dan terciptanya berbagai pengalaman belajar yang diperoleh siswa dengan melibatkan seluruh panca indera, fisik, dan psikis siswa sehingga membantu mengembangkan berbagai potensi yang dimilikinya. Hal-hal tersebut menjadi faktor yang membuat kemandirian belajar siswa lebih baik dengan menggunakan pendekatan saintifik.

Berdasarkan hasil penelitian dan pengolahan data, kesimpulan dalam penelitian ini adalah peningkatan kemandirian belajar siswa dalam matematika yang pembelajarannya menggunakan pendekatan saintifik lebih baik daripada siswa yang pembelajarannya menggunakan pembelajaran konvensional.

\section{E. DAFTAR PUSTAKA}

Boekaerts, Monique; Pintrich, Paul; Zeidner, Mosche. (2000). Handbook of self Regulation. California, USA: Academic Press

Fauzi, K. M. A. (2011). Peningkatan Kemampuan Koneksi Matematis Dan Kemandirian Belajar Siswa Dengan Pendekatan Pembelajaran Metakognitif Di Sekolah Menengah Pertama. In PROCEEDINGS International Seminar and the Fourth National Conference on 
Mathematics Education. Department of Mathematics Education, Yogyakarta State University.

Friedman, Howard. S. \&Schustack, Miriam. W. (2006). Kepribadian; Teori Klasik dan Riset Modern. Jakarta: Erlangga

Kemdikbud. (2013). Pendekatan Scientific (Ilmiah) dalam Pembelajaran. Jakarta: Pusbang prodik

Ruseffendi, E.T. (2010). Dasar-dasar Penelitian Pendidikan \& Bidang NonEksakta Lainnya. Bandung: Tarsito.

Sugiyono (2010). Metode Penelitian Kualitatif Kuantitatif dan R\&D. Bandung : Alfabeta

Sumarmo, U. (2004). Kemandirian Belajar : Apa, Mengapa, dan Bagaimana Dikembangkan pada Peserta Didik. Laporan Penelitian Hibah Pascasarjana UPI. Bandung : Tidak dipublikasikan.

Susilana, R., \& Ihsan, H. (2014). Pendekatan Saintifik dalam Implementasi Kurikulum 2013 Berdasarkan Kajian Teori Psikologi Belajar. Jurnal Edutech, 1(2), 183-193.

Varelas, M and Ford M. (2009). The scientific method and scientific inquiry: Tensions in teaching and learning. USA: Wiley InterScience. 